\title{
Efficacy of Micro-Nutrients, Fungicides and Bio-Agents against Sclerotinia Stem Rot (Sclerotinia sclerotiorum) of Indian Mustard
}

\author{
Pankaj Sharma*, P.D. Meena, Subaran Singh and P.K. Rai
}

ICAR-Directorate of Rapeseed-Mustard Research, Bharatpur-321 303, Rajasthan, India

*Corresponding author

\section{Keywords}

Sclerotinia

sclerotiorum, Bio-

agents,

Formulation, mustard, Sclerotinia rot.

Article Info

Accepted:

07 September 2017

Available Online:

10 October 2017

\section{A B S T R A C T}

Sclerotinia sclerotiorum appears to be among the most nonspecific, omnivorous and successful plant pathogen. The broad host range itself makes control of disease in agricultural crops very difficult, because it restricts the number of non-host crops that can be included in crop rotations. It plays a critical role in reducing the yield in economically important crop like oilseed Brassica. The management of this pathogen is very challenging due to persistence of sclerotia in the soil. Here, we approached diversified management practices with using different amendments for their comparative efficacy. Sclerotinia rot of mustard can be managed by seed treatment (@2 g/kg) and foliar spray (@0.2\%) with Carbendazim resulted in maximum reduction in infection $(88 \%)$ with increased pooled mean seed yield $(2439 \mathrm{~kg} / \mathrm{ha})$. The mixed formulation of mustard cake with micronutrients ( $\mathrm{Zn}$ and $\mathrm{B}$ ) was resulted in the reduction in disease infection ranged from $57.4 \%$ to $61.3 \%$. Bio-control agents like Trichoderma, Bacillus subtilis and Pseudomonas fluorescens showed a medium level of disease reduction ranging from $51.3 \%$ to $64.3 \%$.Seed treatment (@6g/kg) and foliar application (@0.6\%) of Trichoderma showed a reduction of 51.3\% disease incidence with yield $(2095 \mathrm{~kg} / \mathrm{ha})$. An individual application of micronutrient was observed with average performance $(<50 \%)$ in controlling the Sclerotinia stem rot. Overall the combination of bio-control agents with suitable chemical application might be better way for eco-friendly management of Sclerotinia rot.The present study will provide an idea for managing the fungus in the field conditions with the combination of chemical as well as biological methods for obtaining the optimum yield with minimum losses.

\section{Introduction}

Sclerotinia sclerotiorum (Lib.) de Bary is a broad range fungal pathogen which attacks more than 500 species of higher plants (Boland and Hall, 1994; Saharan and Mehta, 2008; Sharma et al.,, 2015a). The pathogen can cause serious losses in yield and quality on numerous important field and vegetable crops (Purdy, 1979). Stem rot of Indian mustard caused by S. sclerotiorum (Lib.) de Bary has become important in recent years in India and elsewhere with high disease and severe yield losses (Ghasolia et al., 2004; Sharma et al., 2017). Management of $S$. sclerotiorum is a major challenge faced by plant pathologists. Management is difficult, uneconomical and inconsistent due to the presence of wide host range and long-term survival of the resting sclerotia. Numerous reports indicate that amendment of soil with certain organic or inorganic matters is effective in controlling soil borne pathogens. Soil amendment with mustard cake, sesame 
cake, jamun (Syzygium cuminii) seed powder and poultry manure also found effective in reducing seedling mortality, number of apothecia production, lesion length and disease intensity in mustard (Mehta et al., 2010). As this is a limit to protect the plant from infection, biological control may work well in controlling the germination of ascospores on petal surfaces. Erwinia spp. and Bacillus spp. have been shown to inhibit Sclerotinia in vitro and in vivo and control Sclerotinia rot on bean (Godoy et al., 1990; $\mathrm{Tu}$, 1988). Foliar applications of bio-control agents are important in the Sclerotinia canola system, as the ascospores generally infect senescing petals at the flowering stage (Turkington and Morrall, 1993). Therefore, there is a need for research into bio-control of S. sclerotiorum on canola, specifically, on limiting petal infection by ascospores. Fungicides have been extensively used for the control of S. sclerotiorum in canola, as well as in other crops like soybean, dry bean and some vegetables (Bailey et al., 2000; Budge and Whipps, 2001). Fungicides are effective in reducing severe yield losses (Morrall and Dueck, 1982, Morrall et al., 1985). There was an increase in the percentage of UK oilseed rape crops sprayed to control Sclerotinia from $9 \%$ in 1991 to $44 \%$ in 1993 (Turner and Hardwick, 1995). The application of fungicides can be expensive and also has negative environmental impacts. Moreover, the development of resistance to fungicides in the pathogen population always remains a threat (Gossen et al., 2001). Foliar spray of carbendazim at bloom stage provided significant disease reduction and highest seed yield among the different treatments over control (Sharma et al., 2011). During the early eighties, SR of rapeseed/canola in Canada was managed by spraying fungicide Benlate with aerial application. In the absence of epidemiological information, especially regarding conditions favourable for carpogenic germination and importance of petals, in both initiation and development of infection, the control by aerial application of fungicides was erratic and often unsuccessful. $S$. sclerotiorum survives in infected seeds as dormant mycelia in testae and cotyledons for 3 years or longer. When infected seeds were sown, $88-100 \%$ failed to germinate. Seedlings produced from infected seeds subsequently died from white mold at an early stage, seeds that failed to germinate were rotted by $S$. sclerotiorum ( $\mathrm{Tu}$, 1988). Captan and thiophanate-methyl used in seed treatment were $100 \%$ effective in eradicating the fungus from the infected seeds. Seed treatment with carbendazim also found effective in minimizing the Sclerotinia rot incidence (Sharma et al., 2011). Several strategies including detoxification defence, activation and general inhibition have potential to engineer Sclerotinia resistance. The integrated disease management strategy including cultural, chemical, biological and host resistance should be refined, retested and revalidated under changing environmental conditions. It is necessary to understand disease epidemic in variable environmental conditions. Management of Sclerotinia with chemical fungicides though remains successful. In this study, we used an integrative approach of different amendments including micronutrients, chemicals and biological and their combinations for reduction in Sclerotinia rot disease incidence in oilseed Brassica.

\section{Materials and Methods}

\section{Experimental site}

A field of Indian mustard was established at an experimental farm of the ICARDirectorate of Rapeseed-Mustard Research (DRMR), Bharatpur, India $\left(77^{\circ} 27 \mathrm{E}, 27^{\circ} 12\right.$ $\mathrm{N} ; 178.13 \mathrm{~m} \mathrm{MSL}$ ). The plot had a history of Sclerotinia rot of mustard, and having loam type soil of alkaline $\mathrm{pH}$ (8.0) with tropical dry 
semi-arid climate. The plot was prepared for planting by post-rainy season ploughing and planking. The experiment was performed over five crop seasons (2009-14). The trial was set up as a randomized block design during the fourth week of October using Brassica junceacv Rohini, with each treatment being replicated three times, in $5 \times 3 \mathrm{~m}$ plots and maintaining spacing at $30 \times 10 \mathrm{~cm}$, adjusted at 21 days after sowing. All standards of agronomic practices were recommended.

\section{Treatments}

Among the treatments, micronutrients like $\mathrm{Zn}$ and B were applied in soil @ 25kg/ha and $1 \mathrm{~kg} / \mathrm{ha}$, respectively and foliar spray of B and $\mathrm{K}_{2} \mathrm{SO}_{4}$ was used @ 1g/l. Separately, mustard cake was applied in the soil @2 tonnes/ha. The formulations of $T$. harzianum were applied as seed treatment @ 6g/ kg seed, and foliar spray@6g/l water. Concentration of formulation used for spray was $2 \times 10^{8} \mathrm{cfu} / \mathrm{g}$ for Bacillus subtilis and Pseudomonas fluorescens. Similarly, there commended fungicide, Iprodione, Carbendazim and Tebuconazole for seed treatment @ 2g/kg and foliar spray@1g/l was also applied. Foliar spray was done at 65-70 DAS when crop is in 30 to $50 \%$ bloom.

\section{Disease assessment}

The total numbers of infected and noninfected plants were counted. A plant was considered to be infected if it showed any level of infection, whether it was a basal stalk infection or an upper canopy pod infection.

A percentage of infected plants (disease incidence, DI) was calculated for each plot. Seed yield was recorded in each treatment at harvest. Per cent oil content was analyzed using Near Infra-Red (NIR) in intact seed for individual plots.

\section{Results and Discussion}

Sixteen treatments including control were laid out in RBD with $5 \times 3 \mathrm{~m}$ size plots and $30 \mathrm{x}$ $10 \mathrm{~cm}$ plant spacing, each treatment was replicated thrice. Indian mustard cv. Rohini was sown in third week of October during five (2009-10 to 2013-14) years. Among different treatments, zinc (@25Kg/ha) and Boron (@1 Kg/ha) as micronutrient and $\mathrm{K}_{2} \mathrm{SO}_{4}$ (foliar spray@0.1\%) used as macronutrient sources, were applied in soil either individually or in combination with the other amendments. Soil application of mustard cake@2tonne/ha individually or combination with zinc and boron was used. Fungal bio-agent Trichoderma (0.6\%) and bacterial $P$. fluorescens $\left(10^{8} \mathrm{cfu} / \mathrm{ml}\right)$ and Bacillus subtalis $\left(10^{8} \mathrm{cfu} / \mathrm{ml}\right)$ were used as foliar spray. Similarly, fungicide, tebuconazole foliar spray @ 2.5g/l and iprodione, carbendazim seed treatment @ $2 \mathrm{~g} / \mathrm{kg}$ and foliar spray @ 1g/l were also applied. A significant reduction in Sclerotinia infection $(88 \%)$ with minimizing in disease incidence $(12.5 \%)$ was observed on seed treatment with carbendazim $(2 \mathrm{~g} / \mathrm{Kg})$ and foliar spray $(0.2 \%)$. In the similar treatment, pooled mean yield was observed at optimum @ $2439 \mathrm{Kg} / \mathrm{ha}$ with $44.4 \%$ increase in yield over control. There was no such variation was observed in oil per cent and 1000 seeds weight. It showed that these amendments did not affect the quality parameters of the crop. Among these amendments, maximum disease prevalence observed in treatment, (soil application boron@1 Kg/ha and foliar spray @ $0.1 \%$ ) was $29 \%$ with decrease pooled mean seed yield and per cent seed yield as compare to control. Reduction in Sclerotinia infection was generally observed more than $50 \%$ except individual micronutrients application excluding $\mathrm{K}_{2} \mathrm{SO}_{4}$ foliar spray. Significantly less disease and higher yields were obtained in treated plots as compared to untreated plots (Table 1). 
Table.1 Effect of different micro-nutrient, bio-agents and fungicides on Sclerotinia stem rot in Indian mustard cv. Rohini during 2009-10 to 2013-14

\begin{tabular}{|c|c|c|c|c|c|c|c|}
\hline S.N. & Treatment & $\begin{array}{l}\text { \% Sclerotinia } \\
\text { infection* }\end{array}$ & $\begin{array}{c}\% \\
\text { Sclerotinia } \\
\text { reduction } \\
\text { over control* }\end{array}$ & $\begin{array}{c}\text { Pooled mean } \\
\text { Seed yield } \\
\text { (kg/ha) }\end{array}$ & $\begin{array}{l}\text { \% increase in } \\
\text { yield over } \\
\text { control }\end{array}$ & Oil (\%) & $\begin{array}{l}1000 \text { seed } \\
\text { weight }(g)\end{array}$ \\
\hline 1 & SA Zinc $(25 \mathrm{~kg} / \mathrm{ha})$ & $22.5(28.3)^{2}$ & 44.9 & 2024 & 19.9 & 41.7 & 4.7 \\
\hline 2 & SA Boron $(1 \mathrm{~kg} / \mathrm{ha})+\mathrm{FS}(0.1 \%)$ & $23.6(29.0)^{2}$ & 42.2 & 2316 & 37.2 & 42.4 & 4.9 \\
\hline 3 & FS Boron $(0.1 \%)$ & $21.2(27.4)^{1}$ & 48.1 & 2302 & 36.3 & 42.0 & 4.2 \\
\hline 4 & $\mathrm{FS} \mathrm{K}_{2} \mathrm{SO}_{4}(0.1 \%)$ & $12.5(20.7)^{1}$ & 69.4 & 2374 & 40.6 & 42.2 & 4.4 \\
\hline 5 & SA Mustard cake (2 tonne/ha) & $19.4(26.0)^{3}$ & 52.5 & 2194 & 29.9 & 42.1 & 4.5 \\
\hline 6 & SA Zinc $(25 \mathrm{~kg} / \mathrm{ha})+$ Boron $(1 \mathrm{~kg} / \mathrm{ha})$ & $20.1(26.6)^{2}$ & 52.7 & 2299 & 36.1 & 42.3 & 4.9 \\
\hline 7 & $\begin{array}{l}\text { SA Zinc }(25 \mathrm{~kg} / \mathrm{ha})+\text { Mustard cake }(2 \\
\text { tonne/ha) }\end{array}$ & $16.0(23.5)^{2}$ & 60.8 & 2312 & 36.9 & 42.3 & 4.6 \\
\hline 8 & $\begin{array}{l}\text { SA Boron }(1 \mathrm{~kg} / \mathrm{ha})+\text { Mustard cake }(2 \\
\text { tonne/ha) }\end{array}$ & $15.8\left(23.2^{2}\right)$ & 61.3 & 2241 & 32.7 & 42.7 & 4.6 \\
\hline 9 & $\begin{array}{l}\text { SA Zinc }(25 \mathrm{~kg} / \mathrm{ha}), \text { Boron }(1 \mathrm{~kg} / \mathrm{ha})+ \\
\text { Mustard cake ( } 2 \text { tonne/ha) }\end{array}$ & $17.4(24.6)^{2}$ & 57.4 & 2274 & 34.7 & 42.4 & 4.8 \\
\hline 10 & ST $(6 g / k g)+F S$ Trichoderma $(0.6 \%)$ & $19.9(26.3)^{2}$ & 51.3 & 2095 & 24.1 & 41.5 & 4.7 \\
\hline 11 & FS P. fluorescens $\left(10^{8} \mathrm{cfu} / \mathrm{ml}\right)$ & $14.6(22.5)^{2}$ & 64.3 & 2238 & 32.5 & 41.7 & 4.4 \\
\hline 12 & FS Bacillussubtalis $\left(10^{8} \mathrm{cfu} / \mathrm{ml}\right)$ & $18.3(25.3)^{1}$ & 55.2 & 2110 & 25.0 & 42.4 & 4.6 \\
\hline 13 & $\begin{array}{l}\text { ST Iprodione+ Carbendazim }(0.2 \%)+\text { FS } \\
(0.1 \%)\end{array}$ & $9.8(18.2)^{2}$ & 76.0 & 2405 & 42.4 & 41.6 & 4.6 \\
\hline 14 & ST+FS Carbendazim $(0.2 \%)$ & $4.9(12.5)^{5}$ & 88.0 & 2439 & 44.4 & 41.9 & 4.6 \\
\hline 15 & $\begin{array}{l}\text { ST Carbendazim }(0.2 \%)+\text { FS Tebuconazole } \\
(0.1 \%)\end{array}$ & $5.1(12.9)^{2}$ & 87.5 & 2430 & 43.9 & 41.8 & 4.5 \\
\hline \multirow[t]{3}{*}{16} & Control (no treatment) & $40.9(39.7)^{5}$ & 0.0 & 1688 & 0.0 & 40.7 & 4.2 \\
\hline & $\mathrm{CD}(5 \%)$ & 4.03 & & 142.6 & & NS & NS \\
\hline & $\mathrm{CV}$ & 6.41 & & 6.32 & & 1.68 & 5.61 \\
\hline
\end{tabular}

* Figures in parentheses are arc sin transformed while others are actual values

*Pooled mean of 5 years (2009-10 to 2013-14); Superscript values are number of year treatment taken. 
Fig.1 Comparative efficacy of different treatments on reduction in diseases and increase in yield

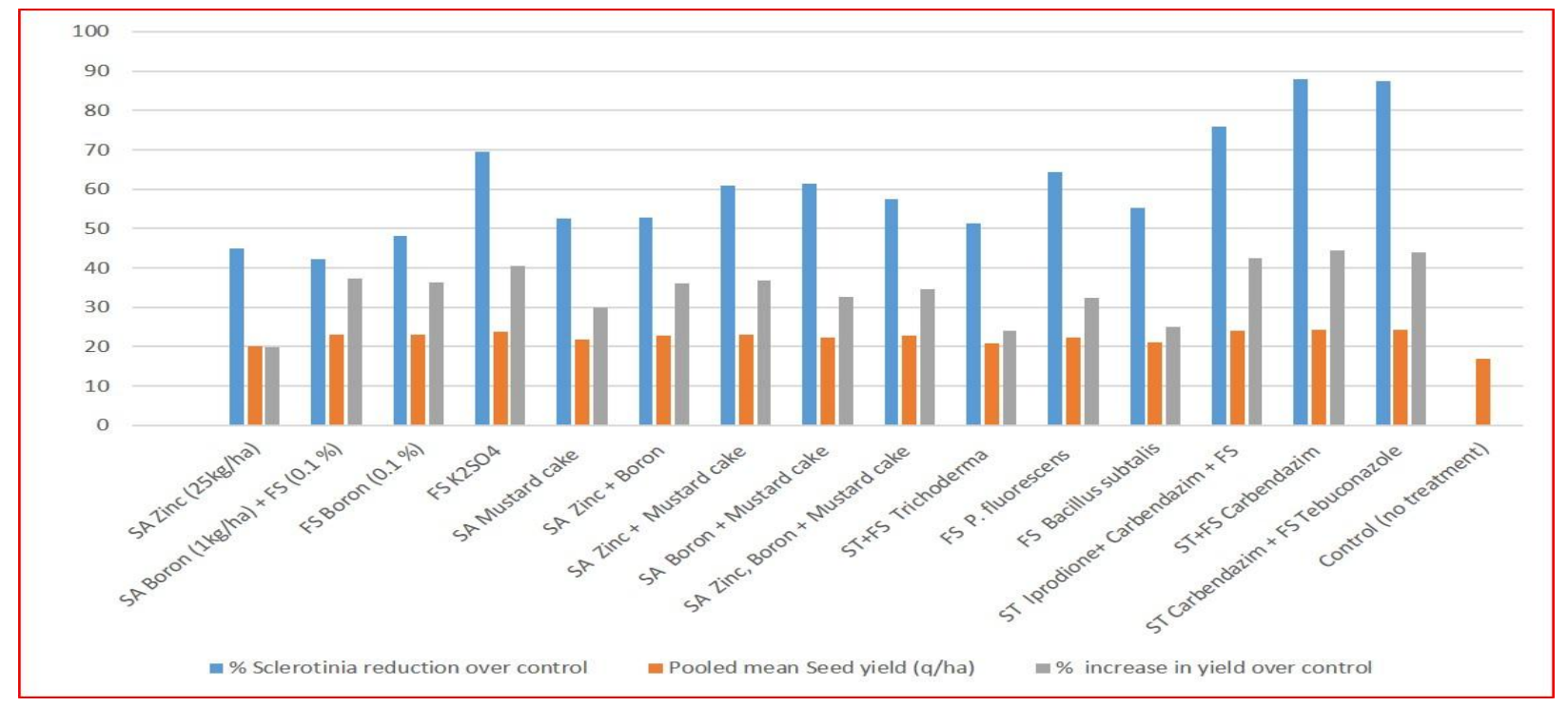

The application of mustard cake with combination of micronutrients reduces the disease infection ranged from $57.4 \%$ to $61.0 \%$.

The disease was controlled in better way with application of fungicides likeiprodione, carbendazim and tebuconazole ranged from 76.0 to $88.0 \%$. All of these fungicides significantly reduced Sclerotinia rot incidence compared with the untreated control on a consistent basis.

The reductions in disease incidence resulted in a significant increase in yield over the untreated control as well. Iprodione previously has been reported to provide control of Sclerotinia rot on rapeseed in Canada (Thomson et al., 1984). Tebuconazole was also reported to reduce Sclerotinia rot severity on soybean (Glycine max) (Mueller et al., 2002) (Fig. 1).

Increased concern over the impact of chemical pesticides on the environment has resulted in the increased interest in bio-control strategies for the management of $S$. sclerotiorum. The most predominantly studied bio-control agents for the management of $S$. sclerotiorum include mycoparasitic fungi and hypovirulent strains of the target fungus. Antagonists like plant growth promoting rhizobacteria are exploited for the management of both foliar and soil borne pathogens of various economically important crop plants. The successful use of bio-agents relies on an effective delivery system and subsequent survival of bacteria in the infection court. Since the primary infection of $S$. sclerotiorum on canola occurs through ascosporic infection of senescing petals (Adams and Ayers, 1979), the bacterial strains were delivered to petals as foliar spray. In this investigation, bacterial antagonists such as Bacillus subtilis and Pseudomonas fluorescens were used and observed the reduction in the Sclerotinia rot with $55.2 \%$ and $64.3 \%$, respectively. Fungal bio-agent Trichoderma and bacterial antagonists (B. subtilis and $P$. fluorescens) showed a medium level of disease reduction in oilseed Brassica compare to fungicides application.

The potential for antagonistic bacteria to control plant diseases has been demonstrated in several crops. However, the efficiency of bio-agents can be improved through elucidation of the mechanism of action. Plants may be protected against pathogens by way of endogenous defense mechanisms that are triggered in response to the attack of either an insect or pathogen (Heil, 2001). 
Induced resistance by bacterial antagonists in several crops is associated with the enhancement of lignification and stimulation of host-defense enzymes and synthesis of pathogenesis-related (PR) proteins (Hammerschmidt and Kuc, 1995). For successful control of SR in oilseed rape and mustard the potential mycopara site must therefore, be applied both aerially and in the soil. In this regard, results of several studies by Meena et al., (2014) showing significant effectiveness of $T$. harzianumi applied as soil inoculants, seed treatment and foliar spray, singly or in combination, in controlling SR in mustard is a step in the right direction.

Although senescing mustard petals need to be present for S. sclerotiorum ascospores to infect (Adams and Ayers, 1979), other factors such as weather and apothecia development also need to be considered for the best time to apply a fungicide. Using disease forecasting models (Sharma et al., 2015b), which predicts the development of apothecia, or measuring petal infestation may provide guidance in determining when to apply a fungicide.

These studies thus conclusively demonstrate that Sclerotinia stem rot of mustard can be effectively and economically managed with increased seed yield, oil contents and 1000 seed weight by seed treatment (@ $2 \mathrm{~g} / \mathrm{Kg}$ ) and foliar spray of Carbendazimor foliar spray (@ 0.2\%) at 65-70 DAS with Pseudomonas fluorescens $\left(10^{8} \mathrm{cfu} / \mathrm{ml}\right)$.

\section{Acknowledgments}

We sincerely acknowledge Director, DRMR, Bharatpur (Rajasthan), India, for providing necessary facilities to carry out this research work.

\section{References}

Adams, P.B., and Ayers, W.A. 1979. Ecology of Sclerotinia species. Phytopathology 69: 896-899.

Bailey, K.L., Johnston, A.M., Kutcher, H.R.
Gossen, B.D. and Morrall, R.A.A. 2000. Managing crop losses from foliar diseases with fungicides, rotation, and tillage in the Saskatchewan Parkland. Canadian J Plant Sci 80: 169-175.

Boland, G.J., and Hall, R. 1994. Index of plant hosts of Sclerotinia. Canadian J Plant Pathol 16: 93-108.

Budge, S.P., and Whipps, J.M. 2001. Potential for integrated control of Sclerotinia sclerotiorum in glasshouse lettuce using Coniothyrium minitans and reduced fungicide application. Phytopathology 91: 221-227.

Ghasolia, R.P., Shivpuri, A. and Bhargava, A.K. 2004. Sclerotinia rot of Indian mustard (Brassica juncea) in Rajasthan. Indian Phytopathol 57: 76-79.

Godoy, G., Steadman, J.R., Dickman, M.B. and Dam, R.1990. Use of mutants to demonstrate the role of oxalic acid in pathogenicity of Sclerotinia sclerotiorum on Phaseolus vulgaris. Physio Mol Pl Pathol 37:179-191.

Gossen, B.D., Rimmer, S.R. and Holley, J.D. 2001. First report of resistance to benomyl fungicide in Sclerotinia sclerotiorum. Plant Dis 85: 1206.

Hammerschmidt, R., and Kuc, J. 1995. Induced Resistance to Disease in Plants. Kluwer Academic Publishers, Dordsecht, the Netherlands, p. 182.

Heil, M., 2001. The ecological concept of induced systemic resistance (ISR). Eur $J$ Plant Pathol 107: 137-146.

Meena, P.D., Chattopadhyay, C., Meena, P.S., Goyal, P. and Kumar, V.R. 2014. Shelf life and efficacy of talc-based bioformulations of Trichoderma harzianum isolates in management of Sclerotinia rot of Indian mustard (Brassica juncea). Ann Plant Protect Sci 22: 127-135.

Mehta, Naresh, Hieu, N.T. and Sangwan, M.S. 2010. Management of white stem rot (Sclerotinia sclerotiorum) of mustard with organic soil amendments. $\mathrm{J} \mathrm{Mycol} \mathrm{Pl}$ Pathol 40: 238-243.

Morrall, R.A.A., and Dueck, J. 1982. Epidemiology of Sclerotinia stem rot of 
rapeseed in Saskatchewan. Canadian J Pl Pathol4: 161-168.

Morrall, R.A.A., Verma, P.R. and Dueck, J. 1985. Recent progress in chemical control of Sclerotinia stem rot in western Canada. Med Fac Landbouww Rijksuniv Gent 50: 1189-1194

Mueller, D.S., Dorrance, A.E., Derksen, R.C., Ozkan, E., Kurle, J.E., Grau, C.R., Gaska, J.M., Hartman, G.L., Bradley, C.A. andPedersen, W.L. 2002. Efficacy of fungicideson Sclerotinia sclerotiorum and their potentialfor control of Sclerotinia stem rot on soybean. Plant Dis 86: 26-31.

Purdy, L.H., 1979. Sclerotinia sclerotiorum: history, diseases and symptomatology, host range, geographic distribution, and impact. Phytopathology 69: 875-880.

Saharan, G.S., and Mehta, Naresh. 2008. Sclerotinia diseases of crop plants: Biology, ecology and disease management. Springer Science + Business Media B.V. The Netherlands, 485p

Sharma, Pankaj, Meena, P.D., Kumar, Amerendra, Kumar, Vinodand Singh, D. 2015b. Forewarning models for Sclerotinia rot (Sclerotinia sclerotiorum) in Indian mustard (Brassica juncea). Phytoparasitica 43:509-516. doi: 10.1007/s12600-015-0463-4.

Sharma, Pankaj, Meena, P.D., Rai, P.K., Kumar, S. and Siddiqui, S.A. 2011. Evaluation of soil amendments, botanical and fungicide against Sclerotinia sclerotiorum causing stem rot of Indian mustard. J Mycol Pl Pathol 41: 151
Sharma, Pankaj, Meena, P.D., Verma, P.R., Saharan, G.S., Mehta, Naresh, Singh, Dhiraj and Kumar, Arvind. 2015a. Sclerotinia sclerotiorum (Lib.) de Bary causing Sclerotinia rot in oilseed Brassicas: A review. Journal of Oilseed Brassica 6 (S): 1-44.

Sharma, Pankaj, Rai, P.K., and Meena, P.D. 2017. Present an emerging biotic stress challenges of oilseed Brassica. In Souvenir: International Seminar on Oilseed Brassica (ISOB), SIAM Jaipur. Feb 23-27, 2017. pp. 27-34.

Thomson, J.R., Thomas, P.M. and Evans, I.R. 1984. Efficacy of aerial application of benomyl and iprodione for the control of Sclerotinia stem rot of canola (rapeseed) in central Alberta. Can J Plant Pathol 6:75-77.

Tu, J.C., 1988. The role of white mold-infected white bean (Phaseolus vulgaris L.) seeds in the dissemination of Sclerotinia sclerotiorum (Lib.) de Bary. $J$ Phytopathol 121: 40-50.

Turkington, T.K., and Morrall, R.A.A. 1993. Use of petal infestation to forecast Sclerotinia stem rot of canola: the influence of inoculum variation over the flowering period and canopy density. Phytopathology 83: 682-689.

Turner, J.A., and Hardwick, N.V. 1995. The rise and fall of Sclerotinia sclerotiorum, the cause of stem rot of oilseed rape in the UK. Proc 9th International Rapeseed Congress (Murphy D Ed), Cambridge, pp. 640-642.

\section{How to cite this article:}

Pankaj Sharma, P.D. Meena, Subaran Singh and Rai, P.K. 2017. Efficacy of Micro-Nutrients, Fungicides and Bio-Agents against Sclerotinia Stem Rot (Sclerotinia sclerotiorum) of Indian Mustard. Int.J.Curr.Microbiol.App.Sci. 6(10): 620-626. doi: https://doi.org/10.20546/ijcmas.2017.610.076 